\title{
PEMETAAN KULTUR SEKOLAH UNTUK MENDISEMINASIKAN KEUNGGULAN: MODEL GUGUS DARI SEKOLAH INTI KE SEKOLAH IMBAS
}

\author{
Joko Sri Sukardi, Ariefa Efianingrum, Dwi Siswoyo \\ Program Studi Kebijakan Pendidikan, Universitas Negeri Yogyakarta \\ jokosri@uny.ac.id, efianingrum@gmail.com, dwi_siswoyo@uny.ac.id
}

\begin{abstract}
Abstrak
Belum meratanya capaian kualitas pendidikan di sekolah dapat berimplikasi pada ketimpangan kualitas pendidikan antarsekolah. Pada era otonomi daerah, Pemerintah Daerah khususnya Dinas Pendidikan memiliki keleluasaan dan kewenangan dalam memajukan kualitas pendidikan di daerahnya. Pemetaan kultur sekolah yang efektif dengan model gugus penting dilakukan untuk mendapatkan gambaran kualitas serta mengetahui keunggulan dan kelemahan sekolah. Keunggulan sekolah inti dapat didiseminasikan kepada sekolah imbas. Keunggulan yang dimaksud meliputi kualitas akademik maupun non akademik. Praktik yang baik di sekolah inti dapat menjadi rujukan dan inspirasi bagi sekolah imbas. Sekolah imbas dapat mengadopsi dan mengadaptasinya untuk meningkatkan keunggulan sekolah. Sekolah imbas dapat menentukan keunggulan yang sesuai dengan konteks sekolah dan wilayahnya masing-masing. Dengan demikian, semua sekolah berpeluang untuk berkembang dalam memajukan sekolahnya dan ketimpangan kualitas pendidikan antarsekolah dapat diminimalisir.
\end{abstract}

Kata kunci: diseminasi, kultur sekolah, model gugus

\begin{abstract}
The late achievement of education quality in schools has an implication for the inequality of inter-school education. In the era of regional autonomy, local government, especially the Education Agency, has the freedom and authority to advance the quality of education in the region. The mapping school culture with the cluster model from the core school to the affected school would be effective to get a picture of each school quality including academic and non-academic quality. The affected schools can develop excellence in accordance to the school context and their respective regions. Good practice at the core school can be a referral that inspires other schools. Impact schools can adopt and adapt it to develop school excellence. Thus, all schools are likely to thrive in advancing their schools and the quality inequality of inter-school education can be minimized.
\end{abstract}

Keywords: Dissemination, School culture, Cluster model 


\section{PENDAHULUAN}

Pendidikan menghadapi tantangan yang semakin berat di era revolusi industri 4.0. Perubahan cepat yang terjadi membawa implikasi pada perubahan dalam berbagai aspek kehidupan masyarakat, baik yang berpotensi membawa kemajuan maupun yang dapat menimbulkan permasalahan-permasalahan di masyarakat. Membahas pendidikan saat ini sesungguhnya juga memikirkan pendidikan yang lebih antisipatoris (Buchori, 2001). Pendidikan perlu mengikuti dan menyesuaikan dengan perkembangan yang terjadi di masyarakat supaya dapat mengantisipasi berbagai perubahan di masa depan. Asumsinya bahwa dalam penyelenggaraan pelayanan pendidikan perlu melihat dan menjangkau jauh ke depan dengan mempertimbangkan suasana zaman yang akan dihadapi oleh generasi berikutnya.

Ki Hadjar Dewantara (1967) mengungkapkan bahwa pendidikan berlangsung dalam tri sentra/tri pusat pendidikan, yaitu: keluarga, perguruan/sekolah, dan pergerakan/masyarakat. Dalam konteks perubahan, terdapat pusat pendidikan lain yang perlu menjadi perhatian karena memiliki pengaruh kuat dan menjadi acuan baru bagi masyarakat, yaitu media dengan segala kekuatannya. Dalam berbagai zaman, pendidikan mestinya tidak mengabaikan tujuan esensialnya sebagai proses pemanusiaan dalam menyiapkan manusia menghadapi tantangan hidup yang senantiasa mengalami perubahan kontekstual sesuai dengan zamannya.

Sebagai dampak dari perubahan paradigma kebijakan nasional yang mengarah pada otonomi daerah, adanya otonomi pendidikan juga berlangsung untuk membuka peluang bagi daerah dalam melakukan pengambilan keputusankeputusan yang bersifat spesifik dan khas sesuai dengan situasi dan kondisi daerahnya. Oleh karena itu, diperlukan analisis dan pengembangan pendidikan yang profesional dengan berpedoman pada pada rencana pembangunan daerah masing-masing. Dalam rangka peningkatan kualitas sumber daya manusia di bidang pendidikan, perlu pemikiran kritis dan analitis untuk menghadapi persoalan pendidikan, khususnya persoalan yang terkait dengan kebijakan 
perbaikan kualitas guru yang menjadi prioritas nasional dan daerah. Selanjutnya, diperlukan kebijakan-kebijakan strategis yang komprehensif dalam hal pembinaan guru profesional untuk perbaikan kualitas pendidikan.

Realitas menunjukkan bahwa pendidikan merupakan salah satu institusi yang lambat untuk berubah, antara lain karena paradigma lama yang masih mengakar dengan kuat (Sindhunata, 2000). Dalam paradigma lama, pendidikan merupakan tanggung jawab dari sekolah dan para pengelola pendidikan. Sedangkan paradigm baru mensyaratkan adanya pelibatan masyarakat sebagai pengemban pendidikan generasi bangsa. Dunia pendidikan dituntut untuk mendekat pada realitas dan persoalan hidup yang terjadi di masyarakat. Sebagaimana terungkap dalam bukunya, Zubaedi (2012) yang menyatakan bahwa sekolah merupakan cermin masyarakat (school is mirror of society). Dalam arti demikian, masyarakat perlu mewarnai proses pendidikan di sekolah, dan institusi pendidikan juga harus berpartisipasi aktif dalam memecahkan berbagai persoalan sosial yang berlangsung di masyarakat. Tilaar (2012) juga menyatakan perlunya reposisi pedagogik, karena pendidikan sejatinya merupakan bagian dari masyarakat dan kehidupan umat manusia. Dengan demikian pendidikan tidak dapat dipisahkan dari kebudayaan.

Namun selama ini kemitraan institusi pendidikan sekolah dan masyarakat masih belum begitu kuat. Antarsekolah juga belum banyak menjalin kemitraan untuk membangun sinergisitas dalam rangka peningkatan kualitas pendidikan, baik menyangkut sumber daya manusia, khususnya pengembangan guru maupun sumber daya yang lain. Kemampuan mengantisipasi kebutuhan masa depan perlu didukung dengan membangun jaringan yang kokoh dengan lembaga-lembaga yang memiliki komitmen kokoh terhadap kemajuan dunia pendidikan. Pemerintah telah mengeluarkan berbagai produk kebijakan seperti Peraturan Pemerintah, Peraturan menteri, dan keputusan Menteri yang diimplementasikan secara dinamis dan berkembang secara terus menerus. Pengembangan kompetensi guru telah dirumuskan dalam Undang-undang Guru No. 14 Tahun 2005. Di dalamnya 
terdapat penjelasan bahwa guru memiliki kompetensi profesional, kompetensi pedagogi, kompetensi sosial, dan kompetensi kepribadian.

Berbagai upaya peningkatan kualitas pendidikan telah dilakukan oleh berbagai pihak, seperti pemerintah, praktisi pendidikan, dan institusi pendidikan yang memiliki kepedulian. Namun kenyataan menunjukkan bahwa masih diperlukan pembenahan-pembenahan. Upaya perbaikan dan peningkatan kualitas sekolah, perlu lebih menitikberatkan pada beberapa aspek, seperti: mengembangkan keunggulan sekolah, kepemimpinan kolaboratif, dan kemitraan untuk mendiseminasikan kualitas pendidikan antarsekolah. Selama ini pengembangan keunggulan sekolah masih diwarnai oleh semangat kompetitif antarsekolah. Kiranya perlu pergeseran menuju pengembangan keunggulan sekolah yang lebih kolaboratif melalui kemitraan antarsekolah.

Kualitas sekolah yang berbeda-beda mengisyaratkan pentingnya upaya peningkatan secara bersama-sama oleh berbagai pihak, baik Dinas Pendidikan maupun sekolah itu sendiri. Kualitas sekolah tidak serta merta ditularkan secara otomatis, namun melalui upaya sinergis. Kajian ini menjadi penting untuk dilakukan sebagai upaya perbaikan sekolah melalui pemetaan kultur sekolah dengan proses pendiseminasian model gugus, mengingat terdapat beberapa masalah yang ditemui di lapangan, yaitu antara lain

a. upaya perbaikan sekolah yang efektif sering dipersepsikan sebagai pembangunan fisik (material) semata-mat;

b. budaya sekolah belum dilihat sebagai faktor penentu dalam usaha pengembangan kualitas sekolah;

c. warga sekolah seringkali belum dilibatkan dan belum mendapatkan peran yang memadai;

d. upaya perbaikan di suatu sekolah seringkali tidak melibatkan sekolah lain melalui kegiatan kolaboratif dan kolegial, sehingga kurang terjadi diseminasi keunggulan dan kualitas antarsekolah.

Kultur sekolah dapat dikembangkan melalui kebijakan pendidikan. Kebijakan pendidikan memiliki pengertian sebagai kebijakan publik dalam bidang 
pendidikan. Kebijakan pendidikan adalah segenap serangkaian proses yang merupakan hasil perumusan langkah strategis pendidikan yang diuraikan dalam penjabaran visi dan misi pendidikan, untuk mencapai tujuan pendidikan dalam masyarakat (Tilaar \& Nugroho, 2008: 140). Sedangkan Mark Olsen \& Anne-Maie O’Neil mengemukakan bahwa kebijakan pendidikan merupakan faktor kunci keunggulan, bahkan menjadi penentu eksistensi negara dalam konteks percaturan global yang sarat dengan persaingan. Oleh karena itu, kebijakan pendidikan perlu mendapat tempat dan prioritas utama di era globalisasi. Argumennya bahwa globalisasi membawa nilai-nilai demokrasi. Demokrasi perlu didukung oleh pendidikan supaya memberikan hasil yang efektif (Riant Nugroho, 2008: 36).

Sementara itu pada bagian lain dijelaskan bahwa kebijakan pendidikan merupakan turunan dari kebijakan publik, dengan kata lain kebijakan publik dalam bidang pendidikan. Kebijakan pendidikan perlu dikembangkan sebangun dengan kebijakan publik sesuai dengan konteks kebijakan publik secara umum, yaitu kebijakan pembangunan. Maka kebijakan pendidikan sebagai bagian dari kebijakan publik perlu dipahami sebagai kebijakan yang bertujuan membangun bidang pendidikan (Riant Nugroho, 2008: 37).

Peningkatan kompetensi guru untuk memperbaiki kualitas lembaga pendidikan dapat didukung oleh faktor statik, akan tetapi faktor statik yang memadai belum dapat menjamin tingginya pencapaian kualitas pada lembaga pendidikan. Peningkatan kualitas kebijakan lembaga pendidikan menjadi suatu isu yang lebih menonjol di negara dunia ketiga, dengan pertimbangan dan alasan sebagai berikut

a. meskipun investasi-investasinya besar, bukti dari banyak negara menunjukkan bahwa lembaga pendidikan tidak efisien pengaruhnya pada tingkat literasi dan prestasi siswa,

b. studi yang pernah dilakukan memberi kesan bahwa kualitas lembaga pendidikan yang rendah membatasi pengaruh ekonomik dari perluasan lembaga pendidikan lebih lanjut (Fuller, 1986 : 492). 
Berbagai kajian menunjukkan adanya keterbatasan yang terkait dengan pengetahuan-pengetahuan tentang kecenderugan kualitas lembaga pendidikan, sebagai faktor utama yang menentukan kualitas lembaga pendidikan. Hal ini dapat dimengerti karena pendidikan dan pembelajaran merupakan suatu system yang kompleks dan bekerjanya dipengaruhi oleh banyak faktor. Berfungsinya faktor dinamik dalam peningkatan kualitas lembaga pendidikan serta faktor-faktor statik yang menunjang peningkatan kualitas lembaga pendidikan, dapat bervariasi antarlembaga

Faktor-faktor dinamik kebijakan kompetensi guru pada lembaga pendidikan akan lebih menonjol perannya dalam menunjang pencapaian kualitas lembaga pendidikan. Kualitas kebijakan lembaga pendidikan ini dapat dilihat dari indikator sebagai berikut, seperti pendayagunaan secara optimal sumber-sumber instruksional, efisiensi dalam pengelolaan input-input material, serta aspekaspek non material lembaga pendidikan seperti: penggunaan waktu, penempatan siswa dalam peran belajar yang lebih aktif dan kepemimpinan sekolah.

Sekolah yang efektif memiliki spirit meningkatkan kualitas dan perbaikan kinerja guru yang menjamin agar semua siswa dapat mengembangkan potensinya. Sebaliknya, sekolah yang kurang efektif belum memberi kesempatan kepada seluruh siswa, karena hanya sebagian kecil siswa, khususnya siswa dengan kemampuan belajar cepat (fast learner) yang berpeluang untuk berkembang. Kebijakan perbaikan sekolah (school improvement) merupakan upaya untuk mewujudkan sekolah yang efektif yang dapat mengoptimalkan kemampuan guru. Untuk memperoleh informasi yang akurat, diperlukan suatu kajian mendalam tentang pendidikan persekolahan yang ada. Studi tentang pendidikan persekolahan (schooling), menurut Goodlad (1984: 16), sebagian didorong oleh adanya kepercayaan bahwa kebanyakan usaha perbaikan lembaga pendidikan terdampar pada batu karang ketidaktahuan-ketidaktahuan inti kerja lembaga-lembaga pendidikan pada khususnya. Seymour Sarason mengingatkan bahwa lembaga pendidikan memiliki suatu ciri budaya khas yang membedakan dengan sekolah 
lainnya. Perbedaan tersebut perlu difahami dengan melihat dinamika perubahan pada institusi sekolah.

Kultur atau budaya dimaknai sebagai pandangan hidup yang diakui oleh suatu kelompok masyarakat secara bersama-sama, yang meliputi cara berfikir, berperilaku, bersikap, beserta nilai yang tekandung dalam bentuk material maupun non material. Kultur dimaknai pula sebagai suatu perilaku, nilai-nilai, sikap dan cara hidup yang digunakan untuk beradaptasi dengan lingkungan, dan sebagai cara untuk memecahkan permasalahannya. Secara alamiah, kultur diwariskan melalui proses turun temurun oleh satu generasi kepada generasi berikutnya. Kultur sekolah dengan demikian merupakan budaya yang berkembang dalam konteks sekolah (Deal \& Peterson, 2009. Sekolah adalah institusi utama yang didesain untuk menjamin proses transmisi kultural antargenerasi. Usaha perbaikan sekolah perlu diiringi dengan proses sosialisasi kepada warga sekolah tentang kewajiban anggota komunitas sekolah dalam mengembangkan diri untuk mencapai tujuan yang diharapkan. Usaha tersebut perlu didukung oleh budaya atau kultur sekolah yang kondusif.

Kultur sekolah meliputi jaringan-jaringan kompleks dari tradisi dan tata cara yang telah dibangun dalam waktu yang lama, sebagaimana guru, siswa, orang tua, dan tenaga kependidikan bekerja sama dalam menghadapi krisis dan permasalahannya (Deal \& Peterson, 2009). Deal \& Peterson juga menjelaskan bahwa dalam kultur sekolah terkandung keyakinan dan nilai-nilai bersama yang mengikat seluruh warga suatu sekolah secara kuat (Septiarti, 2017). Kultur sekolah juga memiliki dampak terhadap kinerja dan berperan dalam menentukan perkembangan kualitas sekolah (Hanum, 2011: 115).

Perbaikan sekolah merupakan sebuah proses untuk mengubah kultur sekolah menjadi lebih efektif. Para guru perlu menegakkan komitmen untuk mau berubah dan terlibat dalam perubahan tersebut. Perbaikan sekolah perlu melibatkan guru dalam pengkajian dan revisi praktik pembelajaran maupun praktek pendidikan di sekolah. Penelitian menunjukkan bahwa pengembangan guru dalam perubahan level sekolah merupakan kebutuhan vital (Harris \& 
Lambert, 2003). Namun demikian kegigihan sekolah dalam usaha perbaikan kualitas sekolah sangat dipengaruhi oleh nilai-nilai yang menjadi komitmen bersama segenap komunitas sekolah. Oleh karena itu penanaman nilai-nilai yang dihargai oleh komunitas sekolah memiliki peran yang fundamental dalam menggerakkan komunitas sekolah dalam mewujudkan sekolah yang baik. Pendiseminasian kualitas pendidikan diperlukan sebagai upaya mengurangi ketimpangan kualitas pendidikan antarsekolah.

\section{PEMBAHASAN}

Sebagaimana dikemukakan oleh Olsen \& O’Neil (Riant Nugroho, 2008: 36), kebijakan pendidikan merupakan kebijakan publik dalam bidang pendidikan. Kebijakan pendidikan beroperasi pada berbagai level, yaitu level nasional, daerah, dan sekolah (Riant Nugroho, 2008: 36). Perbaikan sekolah dalam rangka peningkatan kualitas sekolah dapat diupayakan melalui kebijakan nasional, daerah, dan sekolah. Sekolah dapat menjadi pelaksana kebijakan, sekaligus sebagai inisiator perubahan. Kondisi tersebut memerlukan tersedianya SDM kepala sekolah dan para guru yang inspiratif. Guru inspiratif tidak sekedar memiliki kualitas namun mampu memberdayakan dan bahkan mengubah jalan hidup siswa (Naim, 2009). Guru, kepala sekolah, dan sekolah yang berkualitas dapat menginspirasi guru, kepala sekolah, dan sekolah lainnya. Dengan demikian, upaya perbaikan sekolah dapat dilakukan bersama-sama dengan warga sekolah, melalui kemitraan dengan sekolah lain, melibatkan partisipasi masyarakat dan institusi lainnya.

Secara kultural, budaya sekolah merupakan nayawa sekolah yang berisi nilai-nilai, keyakinan, sikap, norma, tradisi, yang dikembangkanndalam kurun waktu yang panjang, dan menjadi acuan sekolah dalam menghadapi dinamika tantangan yang dihadapi sekolah (Zamroni, 2016). Dalam konteks kebijakan, kebijakan pendidikan di sekolah dapat diterjemahkan sebagai seperangkat tujuantujuan, prinsip-prinsip serta peraturan-peraturan yang membimbing dalam pencapaian tujuan pendidikan di sekolah. Untuk memperoleh informasi yang 
akurat, diperlukan suatu studi tentang perlunya kompetensi guru dalam pendidikan persekolahan yang ada. Kajian tentang pendidikan persekolahan (schooling), menurut Goodlad (1984: 16), didorong oleh adanya keyakinan bahwa usaha perbaikan sekolah dapat dilakukan melalui kebijakan pendidikan. Pimpinan sekolah perlu memiliki sikap aktif dan proaktif dalam menyikapi permasalahan pendidikan. Kepemimpinan yang proaktif tidak semata-mata menjalankan kebijakan pendidikan secara aktif, namun juga mengadopsi dan mengadaptasi kebijakan pendidikan secara kreatif dan inovatif sesuai dengan kondisi dan kebutuhan sekolah.

Sekolah tidak semata-mata mengemban peran sebagai institusi yang bertanggung jawab dalam peran pengajaran (teaching) untuk mengembangkan aspek kognitif siswa. Lebih dari itu, dalam kapasitas tertentu, sekolah juga memerankan fungsi untuk mentransmisikan nilai-nilai afektif (educating). Tidak semestinya seluruh fungsi tersebut menjadi tanggung jawab sekolah sendirian, karena sekolah juga memiliki kendala dan keterbatasan (Sairin, 2003:8). Sekolah dapat membuka peluang kerjasama dengan institusi-institusi lainnya. Dinas Pendidikan dapat memetakan sekolah yang ada di daerahnya. Pemetaan tersebut membantu pemerintah dalam mengidentifikasi persebaran mutu sekolah, potensi, keunggulan, persebaran SDM, maupun problem yang dihadapi oleh setiap sekolah. Pemetaan yang telah ada dapat ditindaklanjuti dengan aksi nyata berupa program-program untuk membangun jejaring sosial yang sinergis antarsekolah. Peta keunggulan masing-masing sekolah perlu dimiliki oleh Dinas Pendidikan untuk melihat karakteristik dan ciri khas masing-masing sekolah. Keunggulan tersebut dapat disebarluaskan melalui diseminasi program dari sekolah inti ke sekolah imbas. Perbaikan sekolah (school improvement) merupakan proses perubahan kondisi menjadi lebih baik (Hanum 2011: 115). Sekolah-sekolah yang belum dapat mengembangkan kultur sekolahnya secara optimal dapat mengambil inspirasi dan manfaat berdasarkan praktik baik yang telah dilakukan oleh sekolahsekolah unggul. Dinas Pendidikan berperan penting sebagai fasilitator dan pimpinan sekolah sebagai inisiator dalam upaya perubahan dan perbaikan sekolah. 
Penelitian menunjukkan bahwa pengembangan kualitas SDM merupakan kebutuhan vital untuk perubahan level sekolah (Harris \& Lambert, 2003). Pimpinan sekolah perlu memiliki peta keunggulan SDM di sekolahnya, baik guru maupun siswa. Pimpinan sekolah juga perlu menggelorakan kembali nilai-nilai yang menjadi komitmen bersama komunitas sekolah. Pengembangan nilai-nilai yang disepakati dan diyakini oleh komunitas sekolah memiliki peran fundamental dalam menggerakkan komunitas sekolah dalam mewujudkan sekolah yang baik dalam arti akademik dan non-akademik.

Kalau sekolah ingin berubah, maka yang mula-mula harus berbenah secara progesif adalah pimpinan sekolah dan guru. Pimpinan sekolah secara kontinyu dapat melakukan pemetaan sekolah (school maping) untuk mengetahui gambaran kondisi sumber daya secara individual dan kelompok, seperti prestasi guru, prestasi siswa, dan prestasi sekolah. Hasil pemetaan kultur sekolah dikaji bersama oleh para guru dan kepala sekolah untuk ditemukan program solutif yang akan dipratikkan besama dan mengantisipasi kendala-kendala yang mungkin dihadapi. Pada gilirannya di kemudian hari, dapat dikaji lagi sebagai umpan balik (feedback) dalam melihat sejumlah kemajuan dan kendala-kendala yang dihadapi. Guru secara kontinyu juga membuat pemetaan kelas (classroom mapping) untuk memetakan secara individual dan kelompok, mengenai seberapa tingkat penguasaan dan prestasi siswa pada kelas di mana guru melaksanakan pembelajaran yang mendidik. Mengingat guru merupakan faktor kunci dalam perbaikan sekolah.pada khususnya dan perbaikan pendidikan pada umumnya.

Pada sekolah yang unggul umumnya terdapat pengharapan yang tinggi untuk kesuksesan semua siswa dan kesuksesan sekolah. Sekolah yang baik memiliki standar kepuasan yang tinggi dari orang tua, siswa, dan guru, yang berkaitan dengan iklim sekolah, iklim kelas, hubungan guru-kepala sekolah, kurikulum, pembelajaran yang mendidik. Diseminasi adalah proses penyebaran informasi berdasarkan rencana, arah, dan pengelolaan untuk saling bertukar informasi dan inspirasi tentang inovasi dari sekolah-sekolah lainnya. 
Budaya sekolah memiliki hubungan produktivitas organisasi sekolah. Beberapa pihak menyatakan bahwa pengaruh budaya terhadap produktivitas begitu kuat sehingga mengembangkan budaya yang mendukung efektivitas sekolah sangat penting bagi keberhasilan sekolah (Johnson, Johnson, Snyder, \& Anderson, 1996). Praktik pengembangan kultur sekolah bisa bermacam-macam, sesuai dengan visi dan konteks sekolah. Fokus pengembangan kultur sekolah dapat mengacu pada

a. pengembangan prestasi akademik;

b. pengembangan prestasi non akademik;

c. pengembangan karakter seperti: kultur disiplin, cinta lingkungan, ramah anak, dan lain-lain (Efianingrum, 2013).

Kemitraan sekolah merupakan kegiatan kerjasama dengan prinsip saling berkontribusi antara sekolah yang memiliki keunggulan prestasi dengan sekolah yang berpotensi untuk memperbaiki kondisinya. Faktor pendukung antara lain adanya sistem penggantian kepala sekolah secara periodik yang memungkinkan setiap sekolah dapat berkembang secara dinamis dengan kepemimpinan baru. Faktor penghambat antara lain terlalu banyaknya beban administrasi guru, sehingga pengembangan keunggulan dan inovasi sekolah kurang mendapatkan tempat secara optimal.

\section{SIMPULAN}

Pemetaan kultur sekolah dapat memberikan gambaran tentang kondisi kualitas masing-masing sekolah. Dinas pendidikan dapat melakukannya untuk mengetahui gambaran tentang sejauh mana pemerataan kualitas pendidikan di wilayahnya. Pemetaan kultur sekolah juga dapat menginspirasi para kepala sekolah untuk lebih fokus dalam mengembangkan keunggulan pada sekolahnya masing-masing, baik keunggulan akademik maupun keunggulan non akademik. Sekolah yang telah terlebih dahulu menemukan dan mengembangkan keunggulan, selanjutnya dapat mendiseminasikan praktik yang baik kepada sekolah-sekolah lainnya. Model gugus dapat dipilih untuk mendiseminasikan kualitas pendidikan dari sekolah inti kepada sekolah imbas. Pemetaan kultur sekolah ini memberi 
peluang bagi pemerataan sumber daya (resource sharing) antarsekolah, sehingga paradigma school competitiveness (kompetisi antarsekolah) lambat laun dapat bergeser menuju school collaboration (kolaborasi antarsekolah).

\section{DAFTAR PUSTAKA}

Buchori, Mochtar. 2001. Pendidikan Antisipatoris. Yogyakarta: Kanisius.

Deal \& Peterson. 2011. Shaping School Culture: Pitfalls, Paradoxes, \& Promises. San Francisco: Jossey-Bass.

Deal, Terrence E. \& Peterson, Kent D. 1998. How Leaders Influence the Culture of Schools?. Educational Leadership, Sept. 1998, Vol. 56, Number 1, Pages 28-30.

1999. Shaping School Culture: The Heart of Leadership. San Fransisco: Jossey-Bass Publishers.

Efianingrum, A. (2013). Kultur Sekolah. Jurnal Pemikiran Sosiologi, 2(1).

Hanum, Farida. 2011. Sosiologi Pendidikan. Yogyakarta: Kanwa Publisher.

Johnson, W. L., Johnson, A. M., Snyder, K. J., \& Anderson, R. H. (1996). School Work Culture and Productivity. Journal of Experimental Education, 64(2), 139-156. https://doi.org/10.1080/00220973.1996.9943800

Harrison, Lawrence E. \& Huntington, Samuel P. 2000. Culture Matters: How Values Shape Human Progress?. New York: Basic Books.

Morin, Edgar. 2005. Tujuh Materi Penting bagi Dunia Pendidikan. Yogyakarta : Kanisius.

Muhadjir, Noeng. 2000. Ilmu Pendidikan dan Perubahan Sosial: Teori Pendidikan Pelaku Sosial Kreatif. Yogyakarta: Rake Sarasin.

Ngainun Naim. 2009. Menjadi Guru Inspiratif: Memberdayakan dan Mengubah jalan Hidup Siswa. Yogyakarta: Pustaka Pelajar.

Peterson, Kent. D. 2002. Positive or Negative?. National Staff Development Council.

Sastrapratedja. 2001. Budaya Sekolah. Majalah Ilmiah Dinamika Pendidikan, No. 2/Th. VIII, November, Hal. 1-17.

Sindhunata, 2000. Menggagas Paradigma baru Pendidikan: Demokratisasi, Otonomi, Civil Society, Globalisasi. Yogyakarta: Kanisius. 
Suyata. 2000. Refleksi Sistem Pendidikan Nasional dan Mencerdaskan Kehidupan Bangsa. Paper dalam Pertemuan Pokja Sistem Pendidikan Nasional untuk Mencerdaskan Kehidupan Bangsa.

Tilaar. H.A.R. 2012. Perubahan Sosial dan Pendidikan: Pengantar Pedagogik Transformatif untuk Indonesia. Yogyakarta: Rineka Cipta.

Zamroni. 2016. Kultur Sekolah. Yohgyakarta. Gavin Kalam Utama

Zubaedi. 2012. Pendidikan Berbasis Masyarakat: Upaya Menawarkan Solusi terhadap Berbagai Problem Sosial. Yogyakarta: Pustaka pelajar. 